\title{
BRIGHT ARTIFICIAL LIGHT PRODUCES SUBSENSITIVITY TO CLONIDINE
}

\author{
Steven C. Dilsaver ${ }^{1}$, M.D., Mark J. Majchrzak ${ }^{2}$

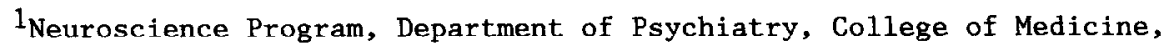 \\ Ohio State University, 473 West 12th Avenue, Columbus, Ohio 43201-1228 \\ 2 Department of Psychiatry, Mental Health Research Institute, \\ University of Michigan, 205 Washtenaw Place, Ann Arbor, Michigan 48109
}

(Received in final form December 1, 1987)

\section{Summary}

The authors used a thermoregulation paradigm to test the hypothesis that chronic treatment with bright artificial light produces subsensitivity to the hypothermic effects of clonidine, an $\alpha_{2}$-agonist. One week of treatment produced blunting of the hypothermic response to clonidine $(p<0.00001)$. These findings are consistent with previous reports that somatic treatments for depression produce subsensitivity of the $\alpha_{2}$-receptor.

Seasonal Affective Disorder (SAD) is a syndrome characterized by recurrent depressions which occur annually (1). This syndrome responds to daily treatment with 2 - 6 hours of bright artificial light (1-5). A mechanism accounting for the efficacy of this treatment has not been identified.

Deficient noradrenergic neurotransmission is implicated in the pathophysiology of endogenous depression $(6,7)$. This could be due to an increased density or supersensitivity of $\alpha_{2}$-receptors (8-11) which, when activated, decrease the release of norepinephrine $(12,13)$.

\section{Materials and Methods}

We used a thermoregulation paradigm to demonstrate that chronic treatment with antidepressants produces supersensitivity to the hypothermic effects of oxotremorine $(14,15)$. We now use this paradigm to verify that bright artificial light produces subsensitivity to the hypothermic effects of clonidine (16-19). We also demonstrate that multiple injections of clonidine do not produce subsensitivity to subsequent injections of itself.

The dependent variable in the experiments reported here was change in core temperature in response to clonidine $\mathrm{HCl}$, an $\alpha_{2}$-agonist. These receptors are predominantly but not exclusively of presynaptic origin. Core temperature was measured using a telemetric thermosensor, the model VM MiniMitter (Mini-Mitter Co., Sun River, OR). These devices emit radio waves at a

This work was performed while Dr. Dilsaver was at the University of Michigan. Please, address all requests for reprints to him at the above address. 
frequency detectable using an AM receiver. Information regarding the validity of this method is available elsewhere (20).

Ful1-spectrum bright artificial light (11,500 lux) was emitted from a bank of eight $122 \mathrm{~cm}$ long Vitalight tubes suspended $50 \mathrm{~cm}$ above the animals. The animals were exposed to the light for 24 hours a day for 7 consecutive days.

The light unit used (Duro Test Corp., Bergen, NJ, Mode1 5599) provides full spectrum light of the variety used to treat SAD (1-5). This unit is used to treat SAD (2). Temperature under the lights was $23-23.5^{\circ} \mathrm{C}$.

Mini-Mitters were implanted into the peritoneal cavities of 10 adult, male Sprague-Dawley rats (mean weight $\pm \mathrm{SEM}=391.8 \pm 14.2 \mathrm{~g}$ ). The animals were allowed five days to recover before beginning experimentation. Experiment 1 involved the measurement of the hypothermic response to clonidine $\mathrm{HCl}, 0.10 \mathrm{mg} / \mathrm{kg}$ ip, prior to exposure to bright artificial light (i.e., at baseline), following one week of light exposure and one week after the withdrawal of phototherapy. Core temperature was measured immediately prior to the injection of clonidine and every 10 minutes thereafter for 120 minutes. The animals wcre subjected to the standard 12 hour light/dark cycle during the baseline and withdrawal phases. Experiment 2 involved the exposure of animals (mean weight \pm SEM $=268.6 \pm 9.9 \mathrm{~g}$ ) to standard fluorescent light at an intensity of 300 lux 24 hours a day for 7 days. This was designed to show that changes in circadian rhythms due to light exposure per se do not account for our findings.

Experiment 3 involved the measurement of core temperature in response to clonidine $\mathrm{HCl}, 0.40 \mathrm{mg} / \mathrm{kg}$ ip, at baseline and one and two weeks later in 7 adult, male Sprague-Dawley rats (mean weight $\pm S E M=243.6 \pm 5.8 \mathrm{~g}$ ) not exposed to bright, artificial light. These animals were subjected to the normal ambient conditions in our vivarium. This involves exposure to standard fluorescent light at an intensity of 300 lux between 0600 and 1800 . The objective of this experiment was to demonstrate that multiple injections of clonidine do not alter the thermic responsiveness to itself. The high dose of clonidine provided a stringent test of the hypothesis that clonidine does not produce subsensitivity to itself when administered weekly.

Data were assessed for significance using student's paired t-test. A11 measures of variance in the text refer to the standard error of the mean (SEM).

\section{$\underline{\text { Results }}$}

Experiment 1: Mean core temeprature at baseline was $37.2 \pm 0.31^{\circ} \mathrm{C}$. Table I summarizes the mean thermic response over the 12 time points of all 10 animals. Nine (9) of the 10 animals exhibited blunting of the hypothermic response to clonidine at $\alpha<0.04$. Further, the mean thermic response of the sample, which was $-1.22 \pm 0.15^{\circ} \mathrm{C}$ prior to 1 ight exposure and $-0.03 \pm 0.10^{\circ} \mathrm{C}$ after chronic light treatment, was significantly blunted $(\mathrm{p}<0.00009, \mathrm{t}=$ $6.74, \mathrm{df}=9)$. One week after the discontinuation of light treatment, the mean hypothermic response of the sample increased to $-1.16 \pm 0.14^{\circ} \mathrm{C}$. This differed significantly from the response during light treatment ( $\mathrm{p}<0.0003$, $\mathrm{t}=5.80, \mathrm{df}=9)$ but did not differ from baseline $(\mathrm{p}<0.80, \mathrm{t}=0.24, \mathrm{df}=$ 9). 


\section{TABLE I}

A

Animal $\begin{gathered}\begin{array}{c}\text { Mean Hypothermic } \\ \text { Response at } \\ \text { Baseline }\end{array} \quad \begin{array}{c}\text { Mean Hypothermic } \\ \text { Response After }\end{array} \\ \text { 1 Week of Light }\end{gathered}$

$$
1
$$

2

$$
-0.55 \pm 0.09
$$$$
-1.81 \pm 0.18
$$

$$
3
$$

4

5

$$
6
$$$$
7
$$$$
8
$$

10

10

$$
\text { B }
$$

$0.35 \pm 0.04$

$0.35 \pm 0.04$
$0.07 \pm 0.04$

$-0.26 \pm 0.05$

$0.21 \pm 0.04$

$0.39 \pm 0.06$

$0.27 \pm 0.06$

$0.00 \pm 0.05$

$0.47 \pm 0.04$

$-0.29 \pm 0.07$

$-0.41 \pm 0.11$

$-0.03 \pm 0.10$
C
Mean Hypothermic Response After
1 Week Light Withdrawn

\begin{tabular}{ll}
$-1.92 \pm 0.12$ & 0.000002 \\
$-1.15 \pm 0.11$ & 0.000001 \\
$-1.50 \pm 0.22$ & 0.003 \\
$-1.30 \pm 0.20$ & 0.000004 \\
$-1.49 \pm 0.12$ & 0.000001 \\
$-0.62 \pm 0.15$ & 0.00002 \\
$-0.43 \pm 0.12$ & 0.000002 \\
$-1.05 \pm 0.16$ & 0.000001 \\
$-0.96 \pm 0.11$ & $\mathrm{n} . \mathrm{s}$. \\
$-1.16 \pm 0.17$ & 0.004 \\
\hline$-1.16 \pm 0.14$ &
\end{tabular}

Baseline vs 1 Week Light 
hypothesis that the effects of bright light result from an alteration of circadian thythms due to constant light exposure. The intensity of light in the rats' cages in our vivarium is 300 lux. The animals demonstrate clearcut circadian changes in motor activity and core temperature in response to turning the lights on or off. Thus, we propose that the results presented here are due to the effects of high intensity light rather than to light per se. The observation that the control sample exhibited a significant increase in its hypothermic response to clonidine of $0.8 \pm 0.28^{\circ} \mathrm{C}(\mathrm{p}<0.02)$ was unexpected. Certainly, significant blunting of the hypothermic response to clonidine following chronic exposure to 300 lux light would suggest that mere exposure to light or alterations in circadian rhythms affect subsensitivity of the mechanism mediating clonidine induced hypothermia. However, the results are opposite this. Bright light but not standard room light produced subsensitivity. Thus, the data are consistent with the hypothesis that bright artificial light affects subsensitivity of presynaptic $\alpha_{2}$ receptors.

Our finding is consistent with reports that tricyclic antidepressants $(21,22)$, monoamine oxidase inhibitors $(23)$, electroconvulsive shock $(24)$, and lithium carbonate (25) (treatments for depression) all subsensitize the $\alpha_{2}{ }^{-}$ receptor. Our data do not prove that bright artificial light subsensitizes the presynaptic $\alpha_{2}$-receptor but are consistent with this possibility. Thus, the capacity to subsensitize $\alpha_{2}$-receptors is a property common to all treatments for depressive disorders which have been assessed for it.

Patients with SAD are typically treated with full-spectrum light at an intensity of 2500 lux. There are advantages to using higher intensities of bright artificial light in preliminary studies. Our objective was to determine whether bright light, as opposed to standard room lighting, produces subsensitivity to the hypothermic effects of clonidine. Use of a high "dose" decreases the probability of accepting a false null hypothesis ("bright artificial light does not produce subsensitivity to the thermic effects of clonidine"). Now that it has been demonstrated that treatment with full-spectrum light at an intensity of 11,500 lux results in decreased sensitivity to clonidine, and possibly subsensitivity of presynaptic $\alpha_{2}{ }^{-}$ receptors, it would be reasonable to evaluate lower "doses" and the effects of administering light for circumscribed periods of time each day. These studies are now under way.

The light unit we used delivers light at an intensity of 2500 lux at a distance of $122 \mathrm{~cm}$ from a patient's face. However, to deliver light at an intensity of $11,500 \mathrm{lux}$, the unit was suspended $50 \mathrm{~cm}$ above the animals. When placed this distance from the face of a patient, there is no discomfort. Thus, it would be feasible to change the current treatment protocols should studies suggest an intensity of light in excess of 2500 lux might be superior.

\section{Acknowledgements}

Supported in part by MH00553-02 and NIH 2507RR05383-5. 


\section{References}

1. N.E. RESENTHAL, D.A. SACK, J.C. GILLIN, et a1, Arch. Gen. Psychiatry 41, 72 (1984).

2. A.J. LEWY, H.A. KERN, N.E. ROSENTHAL, et a1., Am. J. Psychiatry 139, 1496 (1982).

3. S.P. JAMES, T.A. WEHR, D.A. SACK, et al., Brit. J. Psychiatry $\underline{147}, 424$ (1982).

4. T.A. WEHR, F.M. JACOBSEN, D.A. SACK, et al., Arch. Gen Psychiatry 43, 870 (1986).

5. N.E. ROSENTHAL, C.J. CARPENTER, S.P. JAMES, et al., Am. J. Psychiatry $143,356(1986)$.

6. W.E. BUNNEY, J.M. DAVIS, Arch. General Psychiatry 13, 483 (1965),

7. J.J. SCHILDKRAUT, Am. J. Psychiatry 122,509 (1965).

8. R.M. COHEN, I.C. CAMPBELl, M.R. COHEN, et a1., Psychiatry Res. $\underline{3}, 93$ (1980).

9. J.A. GARCIA-SEVILLA, J. GUIMON, P. GARCIA-VALLEJO, et al., Arch. Gen. Psychiatry 43,51 (1986).

10. J.A. GARCIA-SEVILLA, A.P. ZIS, P.J. HOLLINGSWORTH, et al., Arch. Gen. Psychiatry 38,1327 (1981).

11. C.B. SMITH, J.A. GARCIA-SEVILLA, IN: S.Z. LANGER, R. TAKANASHI, T. SEGAWA, M. BRILEY (eds): Advances in Bio-Sciences. New York, Pergamon Press, Vol 40: New Vistas in Depression, 99 (1982).

12. S.Z. LANGER, Pharmacol. Rev. 32, 337 (1982).

13. K. STARKE, Annu. Rev. Pharmaco1. Toxicol. 21, 7 (1981).

14. S.C. DILSAVER, R.M. SNIDER, N.E. ALESSI, Biol. Psychiatry, 23, 495 (1987).

15. S.C. DILSAVER, R.M. SNIDER, J. Clin. Psychopharmacol., In press.

16. W.G. CLARK, Y.C. CLARK, Neurosci. Biobehav. Rev. 4, 281 (1980).

17. A. PLAZNIK, W. KOSTOWSKI, W. DANYSZ, Po1. J. Pharmacol. Pharm. $\underline{35}, 301$ (1983).

18. M.T. LIN, A. CHANDRA, W.C. KO, et al., Neuropharmacol 20, 15 (1981).

19. M.T. LIN, L.R. SHAIN, S.Y. LEU, Naunyn-Schmied Arch. Pharmacol. 326, 124 (1984).

20. R. TOCCO-BRADLEY, M.J. KLUGER, C.A. KAUFFMAN, Infect Immun. 47, 196 (1986).

21. E.M. SELDEN, E.F. DOMINO, Arch. Int. Pharmacodynamics Therapy $\underline{281}, 198$ (1986).

22. A. PILC, J. VETULANI, Brain Res. 238,499 (1982).

23. R.M. COHEN, I.C. CAMPBELL, M. DAUPHIN, et a1., Neuropharmacol 21, 293 (1982).

24. A. PILC, J. VETUlani, Europ. J. Pharm. 80, 109 (1982).

25. C.B. SMITH, S.J. MOSS, P.J. HOLLINGSWORTH, Fed. Proc. 43, 839 (1984). 